\title{
DETERMINASI PERLINDUNGAN HUKUM PEMEGANG HAK ATAS NEIGHBOURING RIGHT DALAM UNDANG-UNDANG REPUBLIK INDONESIA NOMOR 28 TAHUN 2014 TENTANG HAK CIPTA
}

\author{
Muhammad Rizqy Fachrurrauzy \\ Program Studi Magister Ilmu Hukum \\ Pascasarjana Universitas Islam Bandung \\ e-mail: ikiwsetiajati@gmail.com
}

\begin{abstract}
Abstrak - Perjanjian lisensi hak cipta juga merupakan perjanjian konsensualisme, karena terjadinya perjanjian dilandasi dengan sebuah kata sepakat. Namun saat ini ada banyak sekali lembaga penyiaran yang menyalahi perjanjian ini, baik dalam hal live performance musik ataupun acara lain maupun perfilman. Pemahaman masyarakat terhadap Hak Cipta dan Hak Terkait yang merupakan bagian dari Hak Atas Kekayaan Intelektual dirasa masih kurang, sehingga terkadang sulit untuk menegakkan atau mempertahankan hak-hak tersebut, sehingga tidak jarang terjadi pelanggaran atau penyalahgunaan hak. Penelitian ini bertujuan untuk mengetahui dan memahami problematika dan perlindungan hukum pemegang hak atas neighbouring right dalam Undang-Undang Republik Indonesia Nomor 28 Tahun 2014 Tentang Hak Cipta. Metode pendekatan yang digunakan dalam penelitian ini adalah yuridis normatif, dengan spesifikasi penelitian deskriptif analitis. Data yang digunakan adalah data sekunder yang terdiri dari bahan hukum primer, sekunder, dan tersier yang diperoleh dari studi kepustakaan. Hasil dari penelitian ini menunjukkan bahwa Hak Kekayaan Intelektual (HKI) merupakan hak ekslusif yang dimiliki oleh pemegang hak. Hak ini merupakan bentuk penghargaan atas suatu karya yang telah dihasilkan yang mempunyai nilai komersial bagi pemegang hak tersebut. Salah satu hak dalam HKI adalah Hak Terkait (Neighbouring Right) hak ini merupakan sebuah hak untuk pelaku pertunjukan, produser fonogram, atau lembaga penyiaran. Hak ini merupakan salah satu hak untuk mendapatkan pendapatan akan tetapi dalam perkembaganya banyak terjadi permasalahan misalnya mengenai Cover Lagu yang dikomersialisasikan lewat youtube. Penelitian akan melihat bagaimana problematika dan perlindungan hak terkait dalam Undang-Undang Nomor 28 Tahun 2014 Tentang Hak Cipta.
\end{abstract}

\section{Kata Kunci: Hak Kekayaan Intelektual, Hak Terkait, Hak Cipta}

\begin{abstract}
The copyright license agreement is also a consensual agreement because the agreement is based on a deal. However, nowadays, there are a lot of broadcasters' institutions violating this agreement in terms of live music performance or film and other events. Public understanding of Copyright and Related Rights, as a part of Intellectual Property Rights, is felt to be lacking so that it is sometimes difficult to enforce or defend these rights and occurs violations or abuse of rights. This study aimed at determining and understanding the problems and legal protection of right-holders for neighboring rights in the Law of the Republic of Indonesia Number 28 Year 2014 concerning Copyright. The method used normative juridical with descriptive-analytical research specifications. The data used secondary data consisting of primary, secondary, and tertiary legal materials obtained from literature study. The result indicates that Intellectual Property Right (IPR) is an exclusive right owned by right holders. This right is a form of appreciation for a work that has been produced having commercial value for the rights holder. One of the
\end{abstract}


rights in IPR is Neighboring Right that is a right for performers, phonogram producers, or broadcasters. This is one of the rights to get income, but in its development, many problems emerge, for example regarding Cover Songs that are commercialized on YouTube. The study viewed how problems and protection of related rights in Law Number 28 Year 2014 concerning Copyright.

\section{Keyword: Intellectual Property Rights, Neighbouring Rights, Copyrights}

\section{A. PENDAhULUAN}

Karya ilmu pengetahuan atau scientific meliputi ciptaan; buku, program komputer, pamflet, perwajahan atau lay out, karya tulis yang diterbitkan, dan semua hasil karya tulis yang lain; ceramah, pidato, dan ciptaan lain yang sejenis dengan itu; alat peraga yang dibuat untuk kepentingan pendidikan dan ilmu pengetahuan; arsitektur, dan peta. Sedangkan karya seni mencakup; lagu atau musik dengan atau tanpa teks; drama atau drama musikal, tari, kreografi, pewayangan, dan pantomim; seni rupa dalam segala bentuk seperti seni lukis, gambar, seni ukir, seni kaligrafi, seni pahat, seni patung, kloase, dan seni terapan; seni batik, fotografi, dan sinematografi. Adapun karya sastra atau literary work diantaranya adalah; terjemaahan, tafsir, saduran, bunga rampai, database dan karya lain dari hasil pengalih wujudan. Dari uraian mengenai jenis-jenis ciptaan tersebut, karya ilmu pengetahuan dan karya sastra memiliki media tertulis baik yang berupa buku, karya tulis ilmiah, seperti disertasi, tesis, skripsi dan makalah maupun yang berupa artikel untuk jurnal, bulletin, majalah atau koran. ${ }^{1}$

Zaman modern merupakan zaman di mana manusia dituntut untuk mengembangkan diri. Artistik identik dengan seni, karena itulah manusia sering disebut makhluk berkesenian. Manusia dapat dikatakan sebagai makhluk yang memiliki keistimewaan. Adanya suatu keistimewaan ini melahirkan hak dari manusia tersebut untuk mendapat pengakuan, dihargai, dan dihormati. Teori yang sering muncul dalam sejarah pikiran manusia ialah bahwa keistimewaan manusia terletak dalam wujud manusia itu sendiri,

\footnotetext{
${ }^{1}$ Henry Soelistyo, Hak Cipta Tanpa Hak Moral, PT. Raja Grafindo Persada, Jakarta, 2011, Hlm. 185
} 
sebagaimana didapati melalui pikirannya, maka keistimewaan manusia itu bersifat rasional. Hakhak yang didapati orang secara rasional dianggap abadi dan tetap berlaku. Tiap-tiap orang lain, termasuk pemerintah harus mengindahkannya, dengan membuat hukum atas dasar hak-hak alamiah tersebut. $^{2}$

Salah satu aspek hukum yang melindungi hak-hak manusia dalam hak intelektualnya adalah Hukum Hak Kekayaan Intelektual (HKI). Sebagai bentuk penghargaan atas Hak Kekayaaan Intelektual (HKI), perlindungan hukum atas hak-hak tersebut memerlukan perangkat hukum dan mekanisme perlindungan yang memadai. Melalui cara inilah HKI akan mendapat tempat yang layak sebagai salah satu bentuk hak yang memiliki nilai ekonomis. Hukum HKI adalah hukum yang mengatur perlindungan bagi para pencipta dan penemu karya-karya inovatif sehubungan dengan

${ }^{2}$ Maria Alfons, Implementasi Hak Kekayaan Intelektual Dalam Perspektif Negara Hukum, Jurnal legislalasi Indonesia, Vol. 14 No. 03 - September 2017, Hlm. 2 pemanfaatan karya-karya mereka secara luas dalam masyarakat. Karena itu tujuan hukum HKI adalah menyalurkan kreativitas individu untuk kemanfaatan manusia secara luas. $^{3}$

Hak Cipta merupakan salah satu bagian dari kekayaan intelektual yang memiliki ruang lingkup mencakup ilmu pengetahuan, seni dan sastra (art and literary). Hak cipta merupakan bagian dari HKI yang terkandung hak ekonomi dan hak moral. Hak ekonomi yang dimiliki pencipta atau pemegang merupakan hak eksklusif pencipta atau pemegang hak cipta untuk mendapatkan manfaat ekonomi atas ciptaan dan hak moral dapat didefinisikan sebagai hak yang melekat secara abadi pada diri penciptanya. $^{4}$

Saat ini berbagai macam bentuk karya seni dan budaya baik yang berbentuk musik/lagu maupun yang

\footnotetext{
${ }^{3}$ Sulasi Rongiyati, Pelindungan Hukum Hak Kekayaan Intelektual Pada Produk Ekonomi Kreatif, Negara Hukum: Vol. 9, No. 1, Juni 2018, Hlm. 2

${ }^{4}$ Edwita Ristyan, Perlindungan Hak Terkait Terhadap Karya Siaran Skysports yang Dipublikasikan Melalui Situs Internet, Skripsi pada Program Fakultas Hukum Universitas Atma Jaya Yogyakarta, (Yogyakarta: 2017), HIm. 1.
} 
berbentuk sinematografi dapat dengan mudah dilakukan penyiaran yang dilakukan oleh organisasi penyiaran di Indonesia, namun semua kegiatan organisasi penyiaran telah diawasi dan diatur oleh Komisi Penyiaran Indonesia (KPI). Hal ini terjadi karena pada organisasi penyiaran terdapat tanggung jawab yang besar mengenai Hak Terkait maupun Hak Cipta. Hak Terkait (Neighbouring Right) dengan Hak Cipta merupakan hak eksklusif bagi Pelaku yang dapat terdiri dari artis film/telivisi, pemusik, penari, pelawak dan lain sebagainya untuk menyiarkan pertunjukannya. ${ }^{5}$ Yang dimaksud dengan menyiarkan termasuk menyewakan, melakukan pertunjukan umum (Public Performance), mengkomunikasikan pertunjukan langsung (Live Performance), dan mengkomunikasikan secara interaktis suatu karya rekaman suara pelaku. Selain pelaku, juga produser rekaman suara dan lembaga penyiaran mempunyai hak-hak terkait.

${ }^{5}$ Tim Lindsey et al., Hak Kekayaan Intelektual: Suatu Pengantar (Bandung: PT Alumni, 2006), Hlm.102.
Undang-undang hak cipta di berbagai negara tidak saja melindungi hak pencipta atau ciptaannya tetapi juga melindungi hak orang yang mempertunjukkan atau dengan cara lain menyebarkan suatu ciptaan kepada masyarakat luas. Hak terkait adalah hak yang dilekatkan kepada apa saja yang memainkan peranan yang penting dalam penyebaran sebuah karya kepada masyarakat luas. $^{6}$

Seperti hak cipta, hak terkait diakui secara otomatis tanpa prosedur tertentu. Hak terkait juga dilindungi oleh konvensi internasional, seperti Konvensi Internasional tentang Perlindungan Pelaku Pertunjukan, Produser Rekaman Suara, dan Lembaga Penyiaran (International Convention for the Protection of Performers, Producers of Phonograms and Broadcasting Organizations) dan Konvensi tentang Perlindungan Produser Rekaman Suara terhadap Perbanyakan Rekaman Suara Tanpa Izin (Convention for the Protection of Producers of Phonograms Against Unauthorized Duplication of Their

${ }^{6}$ Mochamad Satyo Ariadi, op.cit., Hlm. 3 
Phonograms). Hak cipta dan hak terkait dilindungi sendiri-sendiri dan karena itu perlu mendapat izin terpisah untuk penggunaan masingmasing hak. ${ }^{7}$ Berdasarkan ketentuan Pasal 1 angka 5 Undang-Undang No. 28 Tahun 2014 Tentang Hak Cipta (UUHC) dapat diketahui bahwa yang dimaksud Hak Terkait adalah hak yang berkaitan dengan Hak Cipta yang merupakan hak eksklusif bagi Pelaku Pertunjukan, Produser Fonogram atau Lembaga Penyiaran. Konsep Hak Terkait (Neighbouring Right) muncul sebagai reaksi atas perkembangan teknologi yang memungkinkan penyebaran yang lebih luas dari karya-karya seni. Menurut WIPO, hak terkait adalah cara untuk melindungi "mereka yang membantu pencipta intlektual untuk mengkomunikasikan pesan mereka dan menyebarkan karya-karyanya kepada masyarakat secara keseluruhan". 8

\footnotetext{
${ }^{7}$ Ahmad Faldi Albar, Perlindungan Hukum Penggunaan Musik Sebagai Latar Dalam Youtube Menurutundang-Undang Hak Cipta, Pactum Law Journal, Vol 1 No. 04, 2018, Hlm. 1-2

${ }^{8}$ Cita Citrawinda Priapantja, Hak Kekayaan Intelektual Tantangan Masa Depan (Jakarta:
}

Hak cipta dan hak terkait hanya dilanggar jika benda berwujud dari hak terkait misalnya film, cakram optic dan pita kaset yang ada hak ciptanya diperbanyak atau digandakan langsung dalam bentuk yang sama dengan benda berwujud yang merupakan ciptaan asli tanpa izin dari pemegang hak cipta. Sebagai contoh dari Cakram Optik atau pita kaset tersebut penyanyi dan para pemusik lagu yang direkam suaranya dalam CD ini dalam bentuk suara ataupun bentuk audio visual adalah yang menjadi pelaku dan mempunyai apa yang dinamakan hak terkait. Yang dimiliki oleh penyanyi sebagai pelaku hanyalah sebatas sebagai penyanyi yang menyanyikan lagu yang diperoleh izin untuk dinyanyikan oleh pencipta lagu. Penyanyi hanya terbatas mempunyai hak atas lagu yang dinyanyikannya dan hak inilah yang dinamakan sebagai hak terkait, yang dinamakan Performing Rights penyanyi. ${ }^{9}$ Biasanya yang menjadi pemegang hak cipta atas ciptaan lagu-lagu yang diperbanyak dalam bentuk CD atau

Badan Penerbit Fakultas Hukum Universitas Indonesia, 2003), hlm. 84.

${ }^{9}$ Tim Lindsey, op.cit., Hlm. 104. 
kaset adalah produser rekaman suara, seperti Universal, Sony, Billboard dan sebagainya. Sedangkan yang menjadi pemegang hak cipta atas siaran acara-acara televisi yang dimana juga melibatkan pihak artis, aktor, penyanyi, pelawak ataupun pihak lain yang disiarkan di televisi adalah lembaga penyiaran, seperti RCTI, SCTV, TransTV, Global TV dan sebagainya.

Dengan pengalihan itu lantas timbul perbedaan yang signifikan yang menyangkut addressat perlindungan.

Bila dalam konsepsi Hak Cipta yang dilindungi adalah karya Ciptanya, yaitu ciptaan yang bersifat kebendaan, sebaliknya dalam konsepsi Hak Terkait yang dilindungi adalah hak orang perorangan badan hukum atau lembaga. Fenomena yang terjadi adalah banyaknya aksi panggung (Off Air) yang menggunakan lagu, gerakan maupun tarian dari pihak yang memegang hak cipta akan tetapi dalam pelaksanaanya pemegang hak cipta tidak dapat menikmati hak ekslusif tersebut sebagai akibat masih lemah perlindungan hukum bagi pemegang hak kekayaan intelektual.

Pencipta dan pelaku merupakan bagian dari HKI maka secara langsung pencipta dan pelaku memiliki hak ekonomi dan hak moral dalam diri mereka, adapun pengertian hak ekonomi adalah adalah hak untuk memperoleh keuntungan ekonomi atas HKI dan dikatakan sebagai hak ekonomi karena HKI termasuk sebuah benda yang dapat dinilai dengan uang. ${ }^{10}$ Bagi pencipta atau pemegang hak cipta melakukan perbanyakan ciptaan kemudian dijual dipasaran, maka ia akan memperoleh keuntungan materi dari perbanyakan ciptaan tersebut ataupun rating televisi yang tinggi dalam siaran televisi. Dan bagi pelaku yang diberikan izin oleh pencipta atau pemegang hak cipta juga memperoleh keuntungan dengan cara membawakan suatu karya cipta dari sang pencipta. Sedangkan pengertian hak moral adalah hak agar ciptaan tidak diubah atau dirusak tanpa persetujuan, dan hak untuk diakui

\footnotetext{
${ }^{10}$ Gatot Supramono, Hak Cipta dan Aspekaspek Hukumnya (Jakarta: Rineka Cipta, 2010), Hlm. 45.
} 
sebagai pencipta ciptaan tersebut. Hak ini tidak dapat dihilangkan dengan alasan apapun walaupun hak cipta atau hak terkait telah dialihkan. ${ }^{11}$ Sedangkan hak moral dapat diartikan sebagai keharusan untuk menghormati atau menghargai karya cipta orang lain.

Sejalan dengan hak cipta sebagai hak eksklusif dan hak ekonomi pencipta/pemegang hak cipta mempunyai hak untuk memberikan izin kepada pihak lain untuk mengumumkan, memakai, atau menggandakan ciptaan dan memberikan izin tersebut tidak dapat dilepaskan dari masalah keuntungan dari penggunaan hak cipta. Pemberian izin dari pencipta/pemegang hak cipta kepada orang lain inilah yang disebut dengan lisensi. Pada dasarnya lisensi di bidang HKI tidak semata-mata hanya sekedar perbuatan pemberian izin saja, akan tetapi perbuatan tersebut menimbulkan hak-hak dan kewajiban-kewajiban yang saling bertimbal balik antara pihak satu dengan pihak yang lain. Dengan

\footnotetext{
${ }^{11}$ Haris Munandar dan Sally Sitanggang, Mengenai HAKI (Hak Kekayaan Intelektual) (Jakarta: Erlangga, 2008), Hlm. 17.
}

bertimbal baliknya hak-hak dan kewajiban-kewajiban inilah maka lisensi merupakan sebuah perjanjian yang mengikat mereka. Dalam ilmu hukum perjanjian yang demikian disebut dengan Perjanjian Obligatoire. Perjanjian lisensi hak cipta juga merupakan perjanjian konsensualisme, karena terjadinya perjanjian dilandasi dengan sebuah kata sepakat. ${ }^{12}$ Namun saat ini ada banyak sekali lembaga penyiaran yang menyalahi perjanjian ini, baik dalam hal live performance musik ataupun acara lain maupun perfilman.

Pemahaman masyarakat terhadap Hak Cipta dan Hak Terkait yang merupakan bagian dari Hak Atas Kekayaan Intelektual dirasa masih kurang, sehingga terkadang sulit untuk menegakkan atau mempertahankan hak-hak tersebut, sehingga tidak jarang terjadi pelanggaran atau penyalahgunaan hak.

\section{RUMUSAN MASALAH}

1. Bagaimana Problematika Pemegang Hak atas Neighbouring Right Dalam Undang-Undang Republik

${ }^{12}$ Gatot Supramono, op.cit., Hlm. 49. 
Indonesia Nomor 28 Tahun 2014 Tentang Hak Cipta?

2. Bagaimana Perlindungan Hukum Pemegang Hak atas Neighbouring Right Dalam Undang-Undang Republik Indonesia Nomor 28 Tahun 2014 Tentang Hak Cipta?

\section{B. PEMBAHASAN}

\section{Problematika Pemegang Hak} atas Neighbouring Right Dalam Undang-Undang Republik

Indonesia Nomor 28 Tahun 2014 Tentang Hak Cipta

Hak kekayaan Intelektual (Intellectual Property Rights) adalah hak kebendaan, hak atas sesuatu benda yang bersumber dari hasil kerja otak, hasil kerja ratio. Hasil dari pekerjaan ratio manusia yang menalar. Hasil kerja itu berupa benda immaterial, benda tidak berwujud. ${ }^{13}$ Benda immaterial atau benda tidak berwujud yang berupa hak itu dapatlah dicontohkan seperti hak sewa, hak guna bangunan, hak atas kekayaan intelektual, dan lain sebagainya. Hak milik immaterial termasuk ke dalam hak-hak yang disebut dalam pasal 499 KUHPerdata, karena itu hak milik

${ }^{13}$ Op. Cit, Hlm. 17. immaterial itu sendiri dapat menjadi obyek dari suatu hak benda. Hak benda adalah hak absolute atas sesuatu benda berwujud, tetapi ada hak absolute yang obyeknya bukan benda berwujud, itulah yang disebut dengan nama Hak Atas Kekayaan Intelektual (Intellectual Property Rights). ${ }^{14}$

Hak Atas Kekayaan Intelektual (Intellectual Property Rights) dapat dikategorikan dalam dua kelompok, yaitu:
a. Hak Cipta (Copy Rights)
b. Hak Milik Perindustrian (Industrial Property Rights) Selanjutnya Hak Cipta dapat diklasifikasikan ke dalam dua bagian yaitu: $^{15}$
a. Hak Cipta
b. Hak Terkait (Neighbouring Rights)

Istilah Neighbouring Rights belum memiliki terjemahan yang tepat dalam bahasa hukum Indonesia, ada yang menerjemahkan dengan istilah

\footnotetext{
${ }^{14}$ Mahadi, Hak Milik Immateril (Jakarta: BPHN-Bina Cipta, 1985), Hlm. 5.

${ }^{15}$ Artika Surniandari, Uuite Dalam Melindungi Hak Cipta Sebagai Hak Atas Kekayaan Intelektual (Hki) Dari Cybercrime, Fiat Justisia Jurnal Ilmu Hukum Volume 9 No. 4, Oktober-Desember 2015, Hlm. 4
} 
hak bertetangga dengan hak cipta, ada pula yang menerjemahkan dengan istilah hak yang berkaitan atau berhubungan dengan hak cipta. Menurut OK. Saidin ia menggunakan istilah:

"hak yang bersepadan dengan Hak Cipta oleh karena kedua hak itu (copy rights maupun neighbouring rights) adalah dua hak yang saling melekat berdampingan tetapi dapat dipisahkan satu dengan yang lainnya". ${ }^{16}$

Neighbouring Rights adalah sebuah ungkapan singkat (abbreviated expression) untuk sebutan yang lebih panjang, yang lebih tepat yakni Rights Neighbouring on Copyrights. Dalam terminologi lain Neighbouring Rights dirumuskan juga sebagai Rights Related to, or neighbouring on copyrights (hak yang ada kaitannya dengan, yang ada hubungannya dengan atau berdampingan dengan hak cipta). ${ }^{17}$ Dalam Neighbouring Rights terdapat tiga hak, yaitu: ${ }^{18}$

\footnotetext{
${ }^{16}$ OK. Saidin, Aspek Hukum Hak Kekayaan Intelektual (Jakarta: Raja Grafindo, 2003), Hlm. 14.

${ }^{17}$ Ibid, Hlm. 133.

${ }^{18}$ International Bureau of WIPO, International Protection of Copyrights and NeighbouringRights, WIPO/CNR/ABU/93/2.
}

a. The rights of performing artist in their performances (hak penampilan artis atas tampilannya)

b. The rights producer of phonograms in their phonograms (hak produser rekaman suara atau fiksasi suara atas karya rekaman suara tersebut)

c. The rights of broadcasting organization in their radio and television broadcasts (hak lembaga penyiaran atas karya siarannya melalui radio dan televisi)

Menurut Undang-Undang Nomor 28 Tahun 2014 Tentang Hak Cipta, yang dimaksud dengan hak terkait yaitu:

"Hak Terkait adalah hak yang berkaitan dengan Hak Cipta yang merupakan hak eksklusif bagi pelaku pertunjukan, produser fonogram, atau lembaga Penyiaran". 19

Adapun yang dimaksud dengan hak eksklusif adalah hak yang hanya diperuntukkan bagi Pencipta, sehingga tidak ada pihak lain yang

\footnotetext{
${ }^{19}$ Pasal 1 angka 5 Undang-Undang Nomor 28 Tahun 2014 tentang Hak Cipta.
} 
dapat memanfaatkan hak tersebut tanpa izin Pencipta. Pemegang Hak Cipta yang bukan Pencipta hanya memiliki sebagian dari hak eksklusif berupa hak ekonomi.

Berdasarkan hal itu perlu adanya perlindungan terhadap pemegang hak terkait di Indonesia dengan berkembangnya industri hiburan tanah air dari lagu, film, novel, pentas seni dsb membuat Indonesia menjadi salah satu peluang bagi pelaku industri untuk mendapatkan manfaat. Akan tetapi yang masih menjadi problem adalah banyaknya pelanggaran hak cipta di Indonesia.

Menurut laporan tahunan Special 301 yang dikeluarkan oleh Kantor Perwakilan Perdagangan Amerika Serikat (United States Trade Representatives-UTSR), Indonesia sebelum tahun 2000 merupakan satusatunya negara di ASEAN yang masih masuk kategori priority watch list. Priority watch list artinya pelanggaran atas HAKI masuk kategori yang berat sehingga Amerika Serikat melakukan prioritas pengawasan dengan mitra dagangnya. $^{20}$

Tahun 2007 hingga 2008, Indonesia sempat dalam kategori watch list. Watch list artinya negara yang masuk kategori ini cukup diawasi karena tingkat pelanggaran HAKI dianggap masih belum terlalu berat. Pada tahun 2009, Indonesia kembali diturunkan dan masuk kategori priority watch list11 hingga tahun $2014 .^{21}$

Promblematika kontemporer yang berkaitan dengan hak terkait adalah menyanyikan kembali sebuah lagu (Cover) yang di komersialisasikan lewat Youtube biasanya lagu yang di cover adalah lagu-lagu yang sedang meledak dipasaran. Mengapa dikatakan dikomersialisasikan? Karena penyanyi yang melakukan cover lagu akan mendapatkan pendapatkan dari jumlah penonton maupun iklan.

Salah satu kasus yang ramai di dunia maya saat ini yaitu aransemen (cover) lagu yang dilakukan Hanin

20 Sophar Maru Hutagalung, Hak Cipta Kedudukan \&

Peranannya dalam Pembangunan, Jakarta: Sinar Grafika, 2012, Hlm. 7.

${ }^{21}$ Ibid 
Dhiya yang mengaransemen ulang lagu yang berjudul Akad milik Band Payung Teduh. Pihak manajemen Payuh Teduh menjelaskan bahwa aransemen (cover) lagu yang dilakukan Hanin Dhiya belum meminta izin untuk melakukan aransemen (cover) lagu Akad tersebut. Sedangkan pihak manajemen Hanin Dhiya menjelaskan bahwa pihaknya belum pernah menyampaikan izin secara tertulis atau secara resmi dan hanya dilakukan secara lisan melalui seseorang yang dekat dengan payung teduh. Akan tetapi, pihak manajemen Hanin Dhiya tidak memastikan kembali apakah izin tersebut sampai kepada manajemen Payung Teduh atau tidak. ${ }^{22}$

Neighbouring Rights dalam hukum di Indonesia pengaturannya masih ditumpangkan dengan pengaturan Hak Cipta. Namun jika ditelusuri lebih lanjut Neighbouring Rights itu lahir dari adanya Hak Cipta induk, misalnya liputan pertandingan sepak

${ }^{22}$ DwiRizki,http://www.tribunnews.com/sele b/2017/10/04/minta-maaf-hanin- dhiyabeberkan-soal-izin-cover-lagu-akad-payungteduh-ini-yang-telah-dilakukannya?page =2, akses 23 April 2019. bola adalah Hak Cipta sinematografi, tetapi untuk penyiarannya di televisi yakni berupa hak siaran adalah Neighbouring Rights. Keduanya masih merupakan satu kesatuan, tetapi dapat dipisahkan. Adanya Neighbouring Rights selalu diikuti dengan adanya Hak Cipta, namun sebaliknya adanya Hak Cipta tidak mengharuskan adanya Neighbouring Rights $^{23}$

Seorang artis memiliki hak untuk melarang orang lain yang tanpa persetujuannya membuat atau memperbanyak atau menyiarkan rekaman suara dan atau gambar dari pertunjukannya untuk tujuan komersil. Hak yang melekat pada artis tersebut selain copy rights, juga neighbouring rights. Yang termasuk copy rights adalah hak atas karya rekaman suara, sedangkan neighbouring rightsnya adalah hak atas penampilannya. Hak atas penampilannya itu dapat berwujud seperti video clip (penggalanpenggalan film atau sinematografi). ${ }^{24}$

2. Perlindungan Hukum Pemegang Hak atas Neighbouring Right

${ }^{23}$ OK. Saidin,Op. Cit, Hlm. 14.

${ }^{24}$ Ibid 
Dalam Undang-Undang Republik

Indonesia Nomor 28 Tahun 2014

\section{Tentang Hak Cipta}

Perlindungan Hak Terkait selain diatur dalam undang-undang, saat ini pengaturannya terdapat juga dalam kaidah hukum Internasional, yaitu: ${ }^{25}$

1. Rome Convention for the Protection of Performers, Producers of Phonograms and Broadcasting Organization (1961)

2. Geneva Convention for the Protection of Producers of Phonograms against Unauthorized Duplication of Their Phonograms

3. Brussels Convention Relative to the Distribution of Programme Carring

Signal Transmitted by Satellite

Sedangkan dalam hukum Indonesia pengaturannya tidak disebutkan secara rinci dalam satu peraturan

${ }^{25}$ Bandingkan, Niken Prasetyawati, Perlindungan Hak Cipta Dalam Transaksi Dagang Internasional, Jurnal Sosial Humaniora, Vol 4 No.1, Juni 2011, Hlm. 7-8 khusus tetapi dalam Undang-Undang Nomor 28 Tahun 2014 Tentang Hak Cipta. Perlindungan hukum yang diberikan kepada pemilik hak terkait berdasarkan Undang-Undang Hak Cipta 2014 yakni:

1. Pengaturan mengenai pencatatan/pendaftaran produk hak terkait.

2. Pengaturan pengguna hak terkait bagi yang memanfaatkan hak terkait untuk kepentingan komersial harus membayar royalti kepada pemilik hak terkait melalui Lembaga Manajemen Kolektif.

3. Memberikan ancaman pidana bagi pelanggaran terhadap hak ekonomi pemilik hak terkait sebagaimana diatur dalam UU Hak Cipta.

Dalam Undang-Undang Hak Cipta Nomor 28 Tahun 2014 terdapat larangan mengenai penyebaran konten karya siaran tanpa izin dengan tujuan komersial. Undangundang hak cipta mengkategorikan perbuatan-perbuatan yang dianggap 
tidak melanggar hak cipta atau hak terkait apabila: ${ }^{26}$

1. Penyebarluasan konten hak cipta dan/atau hak terkait melalui media teknologi informasi dan komunikasi tidak bersifat komersial.

2. Dalam hal pemanfaatan ciptaan dan/atau produk hak terkait secara komersial oleh pengguna sepanjang pengguna telah melakukan dan memenuhi kewajiban sesuai perjanjian dengan LMK.

3. Jika mencantumkan sumbernya.

Rome Convention for the Protection of Performers, Producers of Phonograms and Broadcasting Organization adalah suatu konvensi internasional yang dirujuk oleh TRIPs art 14 (6) dalam hubungan dengan hak pelaku (performers), produser fonogram (rekaman suara) dan lembaga penyiaran. Rome Convention disepakati pada tahun 1961 dan hingga sekarang tercatat

${ }^{26}$ OK. Saidin, Op. cit, Hlm. 139. ada 69 negara anggota per 15 Juli 2002 , tidak termasuk Indonesia. ${ }^{27}$

Pasal 3 dari Rome Convention tersebut memberikan definisi: ${ }^{28}$

1. Performers adalah aktor, penyanyi, musisi, penari dan orang lain yang beraksi, menyanyi, mempertunjukkan karya kesasteraan atau artistik.

2. Phonogram adalah fiksasi oral suara dari pertunjukan.

3. Produser Phonogram adalah orang-orang yang atau badan hukum yang pertamatama membuat suara dari pertunjukkan atau suara lainnya.

4. Publikasi berarti menyerahkan copy dari Phonogram kepada publik dalam jumlah yang layak.

\footnotetext{
${ }^{27}$ Mochamad Satyo Ariadi, op.cit., Hlm. 34. ${ }^{28}$ Chairul Anwar, Hak Cipta Pelanggaran Hak Cipta \& Perundang-undangan Terbaru Hak Cipta Indonesia (Jakarta: Novindo Pustaka Mandiri, 1999) Hlm. 25.
} 
5. Reproduksi berarti membuat copy-copy dari fiksasi.

6. Broadcasting berarti transmisi dengan wireless untuk penerimaan publik atas suara atau latar suara.

7. Rebroadcasting berarti penyiaran yang simultan oleh satu organisasi penyiaran dan penyiaran dari organisasi penyiaran lainnya.

Pasal-pasal yang penting dari Konvensi Roma 1961 adalah pasal 10 yang sudah menyatakan bahwa produser dari phonogram akan menikmati hak untuk menguasakan atau melarang reproduksi langsung atau tidak langsung dari phonogram mereka. Dan juga dalam pasal 13 dari Konvensi Roma 1961 menyatakan bahwa organisasi penyiaran akan menikmati hak untuk menguasakan atau melarang: ${ }^{29}$
1. Penyiaran ulang dari siarannya.

\footnotetext{
${ }^{29} \mathrm{Ibid}, \mathrm{Hlm} .26$.
}

2. Fiksasi dari penyiaran.

3. Reproduksi:

a. Dari fiksasi yang dilakukan tanpa persetujuan mereka dari penyiaran mereka

b. Dari fiksasi yang dibuat sehubungan dengan ketentuan-ketentuan pasal 15 dan siaran mereka, kalau reproduksi dibuat untuk maksud berbeda dari hal-hal yang telah ditentukan.

4. Komunikasi kepada publik dari siaran televisi mereka, kalau komunikasi tersebut dibuat ditempat-tempat yang mempunyai akses terhadap pembayaran dari fee entrance, yang hal ini dapat diatur oleh hukum dalam negeri dari Negara yang bersangkutan

Dalam ketentuan konvensi ini ada yang menyebutkan bahwa pemberian jaminan perlindungan tersebut didefinisikan sesuai dengan kebutuhan nasional masing-masing negara anggota, yang berarti dapat diambil kesimpulan bahwa bentukbentuk jaminan perlindungan 
tersebut dapat saja berbeda-beda diantara sesama negara anggota. Untuk lebih jelasnya hal ini dapat dilihat dalam pasal 2 konvensi ini yang terjemahannya berbunyi:

Perlindungan yang diberikan oleh konvensi, didefinisikan sesuai dengan kebutuhan nasional.

1. Demi kegunaan konvensi ini, kebutuhan nasional berarti kebutuhan yang sesuai dengan hukum lokal yang berlaku dimana ada disebut tentang perlindungan yang diberikan:

a. Bagi pemain nasional yang penampilannya mengambil tempat, rekaman atau pengubahan pertama dilaksanakan di wilayah hukum yang berlaku

b. Bagi produser rekaman nasional, yang melakukan rekaman awal dan publikasi awal di wilayah hukumnya.

c. Bagi organisasi penyiaran yang mempunyai kantor diwilayah hukumnya, yang melakukan penyiaran dari transmisi yang terletak di wilayah hukumnya.

2. Perlakuan nasional secara subjektif berupa jaminan perlindungan secara khusus serta pembatasan-pembatasan terhadap keadaan yang memaksa seperti pada konvensi ini. ${ }^{30}$

Geneva Convention for the Protection of Producers of Phonograms against Unauthorized Duplication of Their Phonograms mengatur tentang hak produser rekaman dan Brussels Convention Relative to the Distribution of Programme Carring Signal Transmitted by Satellite menitikberatkan pada pengaturan tentang distribusi program siaran yang menggunakan jaringan transmisi satelit.

Produser rekaman suara berarti orang yang menurut ketentuan hukum untuk pertama kalinya memfiksasikan suara orang lain dalam bentuk karya rekaman suara. Seorang produser berhak mendapat perlindungan hukum terhadap karya

${ }^{30}$ OK. Saidin, op.cit., Hlm. 215 
rekaman suara orang lain yang merupakan hasil kerjanya, bilamana hasil karya rekaman itu ditayangkan ulang oleh pihak lain untuk tujuan komersil.

Berikut ini akan diuraikan tentang hak-hak pelaku, produser, dan lembaga penyiaran.

\section{Hak Pelaku atas} Tampilannya $^{31}$

Istilah pelaku digunakan untuk memperluas cakupan pengertian performers yang tidak hanya terbatas pada ruang lingkup artis semata-mata tetapi juga mencakup seluruh aktivitas manusia yang menampilkan kebolehannya di depan public, yang tidak hanya terbatas pada penampilan yang berlatar belakang kesenian dan kesusastraan.

Di Indonesia untuk hak-hak para pencipta lagu, musisi dan penyanyi untuk meneerima pembayaran royalty dipegang oleh Yayasan Karya Cipta Indonesia (YKCI). Royalty itu berasal dari pemutaran lagu-lagu di berbagai tempat hiburan yang bersifat komersil. YKCI hanya menagih royalty yang berasal dari anggota yayasan. Royalty itu dibayarkan kepada pencipta lagu, musisi dan penyanyi dengan hitungan persentase tertentu. ${ }^{32}$ Persoalan yang dihadapi yakni sikap dan pandangan para pengusaha hiburan yang menganggap bahwa memutar atau menyanyikan lagulagu (yang dilindungi hak cipta atau neighbouring rights) orang lain tidak diwajibkan membayar royalty, padahal dalam aktivitas mereka, pengusaha tersebut menjual hiburan dengan memanfaatkan karya cipta orang lain.

Perlindungan yang sama juga harus diberikan kepada pelaku lain, selain penyanyi yakni pembawa acara, pemandu acara, pembaca berita, para atlit, dan lain-lain. Maka sudah sepantasnya sebagian dari keuntungan itu diserahkan kepada pemegang neighbouring rights. Dengan demikian kreativitas akan tumbuh dengan pesat, dan inilah salah satu tujuan dari perlindungan hukum neighbouring rights.

2. Hak Produser Rekaman ${ }^{33}$

\footnotetext{
${ }^{32}$ Ibid, hlm.139.

33 J.B. Wahyudi, Dasar-Dasar manajemen Penyiaran, Gramedia Pustaka Utama, Jakarta, 1994, Hlm. 40.
} 
Produser rekaman suara biasanya mendapatkan hak untuk merekam suara dari para penyanyi atau musisi. Hak itu dapat diperoleh atas persetujuan pencipta atau orang yang menerima hak dari pencipta. Persetujuan itu dapat berupa lisensi.

Produser juga mengeluarkan dana yang tidak sedikit untuk biaya produksi. Produser tidak hanya berhak mendapat keuntungan dari penjualan kaset atau $\mathrm{CD}$, tetapi berhak juga atas royalty manakala kaset atau CD itu dikumandangkan di tempat-tempat yang bersifat komersil.

3. Hak Lembaga Penyiaran ${ }^{34}$

Dalam kaitannya dengan perlindungan neighbouring rights, radio dan televisi dapat menyiarkan hasil rekaman dengan membayar royalty kepada pemegang hak eksklusif. Hak ekslusif itu adalah lembaga penyiaran pertama atau yang untuk pertama kalinya menyiarkan acara itu.

Adapun hak-hak yang dimiliki oleh lembaga siaran tersebut adalah:

a. Moral Rights, merupakan hak dari performers untuk disebutkan namanya dalam kaitan dengan pertunjukan mereka dan hak untuk menolak kerugian yang ditimbulkan akibat dari pertunjukan mereka.

b. Exclusive Rights, dalam hal reproduksi, distribusi, rental dan rekaman suara secara online terhadap pertunjukan mereka

c. Hak untuk memperoleh pembayaran yang wajar dari siaran dan komunikasi kepada khalayak dari penanyangan ulang siaran mereka

Bila diamati dan dicermati masalah moral rights atau hak moral, kita akan segera mengetahui bahwa hak moral merupakan hak dasar yang dimiliki oleh performers (artis, penyanyi, pemusik dan orang-orang yang berakting, berpidato, mendeklamasikan, memainkan maupun menampilkan karya seni dan kesusastraan dan cerita rakyat) ${ }^{35}$

35 WIPO Performances and Phonograms Treaty, Artcle 2 (a). 
untuk disebutkan namanya. Dalam penampilan sebuah lagu di radio atau televise, penyiar radio wajib menyebutkan nama penyanyi dan penciptanya begitu juga musisinya.

Performers atau pemegang hak mempunyai hak untuk mendapatkan pembayaran yang wajar dari hasil siaran yang disiarkan oleh lembagalembaga penyiaran. Hal ini merupakan hal yang wajar karena lembaga siaran ini mendapatkan keuntungan atau fee dari produsenprodusen yang produknya ditawarkan melalui radio atau televise tersebut dalam bentuk iklan. Inilah wujud dari Property Rights yang dimiliki oleh performers.

Pembayaran royalty adalah merupakan salah satu bentuk implementasi ditegakkannya pengakuan atas hak cipta secara umum dan secara khusus penegakan hak atas Neighboring Rights di kalangan lembaga penyiaran. Hal ini juga tak lain adalah sebagai konsekuensi berlakunya ketentuan TRIPS (Trade Related Aspects of Intellectual Property Rights) di Indonesia, dimana Indonesia adalah salah satu penandatangan Konvensi Roma yang di dalamnya mengatur ketentuan tentang Neighboring Rights ini.

\section{Kesimpulan dan Saran}

\section{Kesimpulan}

Hak Terkait adalah hak yang berkaitan dengan Hak Cipta yang merupakan hak eksklusif bagi pelaku pertunjukan, produser fonogram, atau lembaga Penyiaran. Kemunculan Hak Terkait dengan Hak Cipta di Tanah Air berawal dari munculnya Hak Cipta itu sendiri, karena Hak Terkait merupakan bagian dari Hak Cipta. Dalam perkembangan globalisasi ada banyak sekali karya cipta seperti lagu, film, acara televisi yang sering disalahgunakan oleh orang yang tidak bertanggung jawab seperti memperbanyak, memasarkan dan segala upaya untuk memperoleh keuntungan finansial, sehingga pencipta atau pemilik hak cipta merasa dirugikan baik dari segi Hak Moral maupun Hak Ekonomi. Karena inilah hak terkait dengan hak cipta lahir dengan tujuan untuk melindungi hak performers, produser rekaman dan lembaga penyiaran dari 
penyalahgunaan karya mereka. Perlindungan hukum untuk hak terkait diberikan melalui peraturan perundang-undangan yaitu UndangUndang Nomor 28 Tahun 2014 tentang Hak Cipta juga melalui konvensi konvensi Internasional yaitu Konvensi Roma 1961, Konvensi Jenewa, dan Brussel Convention.

\section{Saran}

Agar perkembangan mengenai Hak Terkait dengan Hak Cipta makin pesat terutama di bidang perlindungan hukumnya, hendaknya dilakukan sosialisasi kepada masyarakat luas terutama masyarakat media agar masyarakat memahami seperti apa dan bagaimana konsep dari Hak Terkait dengan Hak Cipta. Para penegak hukum diharapkan agar dalam menangani perkara pelanggaran Hak Terkait kiranya mempergunakan wewenang yang diberikan undang-undang, hendaknya hukuman yang diberikan benar-benar setimpal dengan pelanggaran yang dilakukan. Hal ini bertujuan untuk mengurangi berbagai bentuk pelanggaran yang dapat merugikan Pelaku Industri Hiburan.

\section{DAFTAR PUSTAKA}

\section{BUKU}

Chairul Anwar, Hak Cipta Pelanggaran Hak Cipta \& Perundangundangan Terbaru Hak Cipta Indonesia, Novindo Pustaka Mandiri, Jakarta 1999

Cita Citrawinda Priapantja, Hak Kekayaan Intelektual Tantangan Masa Depan, Badan Penerbit Fakultas Hukum Universitas Indonesia, Jakarta, 2003

Gatot Supramono, Hak Cipta dan Aspek-aspek Hukumnya, Rineka Cipta, Jakarta, 2010

Haris Munandar dan Sally Sitanggang, Mengenai HAKI (Hak Kekayaan Intelektual), Erlangga, Jakarta, 2008

J.B. Wahyudi, Dasar-Dasar manajemen Penyiaran, Gramedia Pustaka Utama, Jakarta, 1994

Mahadi, Hak Milik Immateril, BPHNBina Cipta, Jakarta, 1985

OK. Saidin, Aspek Hukum Hak Kekayaan Intelektual, Raja Grafindo, Jakarta, 2003

Sophar Maru Hutagalung, Hak Cipta Kedudukan \& Peranannya dalam Pembangunan, Sinar Grafika, Jakarta, 2012

Tim Lindsey et al., Hak Kekayaan Intelektual: Suatu Pengantar, PT Alumni, Bandung, 2006 


\section{JURNAL/SKRIPSI/TESIS/DISERTA}

SI

Ahmad Faldi Albar, Perlindungan Hukum Penggunaan Musik Sebagai Latar Dalam Youtube Menurutundang-Undang Hak Cipta, Pactum Law Journal, Vol 1 No. 04, 2018

Artika Surniandari, Uuite Dalam Melindungi Hak Cipta Sebagai Hak Atas Kekayaan Intelektual (Hki) Dari Cybercrime, Fiat Justisia Jurnal Ilmu Hukum Volume 9 No. 4, OktoberDesember 2015

Edwita Ristyan, Perlindungan Hak Terkait Terhadap Karya Siaran Skysports yang Dipublikasikan Melalui Situs Internet, Skripsi pada Program Fakultas Hukum Universitas Atma Jaya Yogyakarta, Yogyakarta: 2017

Mahmuda Pancawisma Febriharini, Eksistensi Hak Atas Kekayaan intelektual terhadap Hukum Siber, Serat Acitya - Jurnal Ilmiah UNTAG Semarang ISSN : 23022752, Vol. 5 No. 1, 2016

Maria Alfons, Implementasi Hak Kekayaan Intelektual Dalam Perspektif Negara Hukum, Jurnal legislalasi Indonesia, Vol. 14 No. 03 - September 2017

Niken Prasetyawati, Perlindungan Hak Cipta Dalam Transaksi Dagang Internasional, Jurnal Sosial Humaniora, Vol 4 No.1, Juni 2011

Sulasi Rongiyati, Pelindungan Hukum Hak Kekayaan Intelektual Pada Produk Ekonomi Kreatif, Negara Hukum: Vol. 9, No. 1, Juni 2018

\section{UNDANG-UNDANG}

\section{INTERNET}

DwiRizki,http://www.tribunnews.com/s eleb/2017/10/04/minta-maafhanin- dhiya-beberkan-soal-izincover-lagu-akad-payung-teduhini-yang-telahdilakukannya? page $=2$, akses 23 April 
Muhammad Rizqy Fachrurrauzy, Determinasi Perlindungan Hukum Pemegang Hak Atas... 